\title{
Coastal Resources and Management Systems Influenced by Conflict and Migration: Mecúfi, Mozambique
}

Coastal resource utilization and management systems, both traditional and more recently conceived, were studied in Mecufi district, northern Mozambique in a post-conflict situation prior to which a significant migration of people to the coast had occurred. A wide variety of coastal biotopes containing a multitude of resources had been affected in various ways. Intertidal organisms exhibited signs of decreasing abundance and average size, whereas offshore fishes and mangrove forests did not show signs of overutilization. It was observed that traditional coastal management systems were still influential, but that newer initiatives were only beginning to enter into significant dialogue and cooperation with these. In the current circumstances of peace and political stability, the principal threat to coastal management and the interests of local people in Mecufi is considered to be potential loss of common property resources and land tenure in the face of prospects of privatization, but Mozambican authorities are presently addressing these issues with legal reforms.

\section{INTRODUCTION}

Mozambique is situated on the east coast of Africa and has a coastline of $2770 \mathrm{~km}$, stretching from $10^{\circ} 20^{\prime} \mathrm{S}$ to $26^{\circ} 50^{\prime} \mathrm{S}$. Coastal resources contribute significantly to people's livelihoods and to the national economy (1). The country has experienced long periods of conflict during the colonial period until 1975, and subsequently a civil war that lasted until 1992. This resulted in a major migration of people to the coastline for its relative safety, and people had subsequently mainly chosen to stay near to the coast after peace was attained. Assumptions had been made by Mozambican environmental authorities and donor organizations about the impact of these conflicts and movement of people on coastal resources (2), but sparse scientific evidence was available. Little attention had been paid to the existence and role of traditional management systems.

The aim of this study was to examine this complex situation in Mecufi district in the northern part of Mozambique. Coastal resources (both on land and in the sea) were identified in relation to patterns of utilization, and the effects of increased pressure on these resources were assessed. The existence and resilience of traditional management systems among the local Makua-speaking people, about which little is previously documented, were investigated. The effects of more recent coastal management initiatives that have been funded amongst others by Sida, DAN IDA, and NORAD were also considered in this context.

Mecufi district was selected for this study because Mozambican environmental authorities, research institutions and donors had chosen it as a focus of coastal management work and studies since 1992 Both authors had already stayed in or visited the district on several occasions and perceived the need for deeper investigations.

For the purposes of this study, villages in Mecufi district were visited for 4 weeks in October 1998 and 3 weeks in November 1999. Coastal biotopes were visited to identify flora and fauna that were of significance as resources and to assess their ecological status. Semistructured informal interviews were conducted with people of all walks of life in Mecufi district including longstanding residents, more recent immigrants and displaced people (deslocados) who had fled to the coast during the conflict. The views of traditional leaders, religious leaders as well as government administrators at locality, post, district and provincial levels were sought. Existing literature and unpublished reports relevant to coastal ecology and society in Mecufi were reviewed.

\section{THE GEOGRAPHY OF MECUFI DISTRICT}

Mecufi district is situated in Cabo Delgado province in northern Mozambique between $13^{\circ} 06^{\prime} \mathrm{S}$ and $13^{\circ} 26^{\prime} \mathrm{S}$. The district is bounded to the east by the Indian Ocean and by the neighboring districts of Chiure to the south, Ancuabe to the west and Pemba to the north. Pemba is the seat of the capital town of the province. A road southward along the coastline leads from Pemba town to Mecufi district center, a distance of about 44 Ian.

The population of Mecufi district was 37270 according to a census conducted in 1997 (3) comprising about 8000 households. The area of the district is $1192 \mathrm{~km}^{2}$ indicating an overall population density of 31 persons $\mathrm{km}^{-2}$. The district is essentially rural with villages mostly situated close to the coastline and the main road. Most people previously living inland were forced to move for safety towards the coastline during the civil war period in the 1980s, and the majority of these have opted to stay rather than move back after the cessation of conflict. The proportion of females in the population was $51.6 \%$. The principal language spoken is Makua (or Macua), while the administrative language is Portuguese; other languages commonly spoken are Kimwani and Swahili.

The climate is tropical with a temperature range of 20.0 to $31.6^{\circ} \mathrm{C}$, warmest in February and coolest in July, and with an average annual rainfall of $876 \mathrm{~mm}$ mainly falling between December and April (4).

The land is low-lying (maximum elevation $160 \mathrm{~m}$ ) and composed of marine sediments of Cretaceous or recent origin. The soils in northern Mecufi are mainly sandy dune types with ferralitic content giving a reddish color and in some parts higher organic content gives a grey color; in southern Mecufi there are more medium textured alluvial soils with brown to grey color. The terrestrial vegetation is typical of tropical eastern Africa classified as "Zanzibar-Inhambane regional mosaic" (5). Inland there are dense woodlands, dune forests and wooded grasslands where edible fruits, medicinal plants, fuelwood, honey, and hunted meat (including duiker, steenbok, bushbuck, sable antelope, wild pig, hare, guinea fowl and francolin) are important resources. Towards the coastline there are increasing occurrences of agricultural crops in fields (cassava, maize, sorghum, rice, beans, groundnuts and sweet potatoes) and grassy fallow areas interspersed with orchards of exotic trees (including cashews and mangoes). River basins are vegetated by riverine forests or swamp grasslands (flooded during the rainy season) and closer to the shore by mangrove forests. Above the beach crest there are numerous plantations of coconut palms, groves of Casuarina 
Farming of Eucheuma seaweed during a spring low tide period. Photo: I. Bryceson.

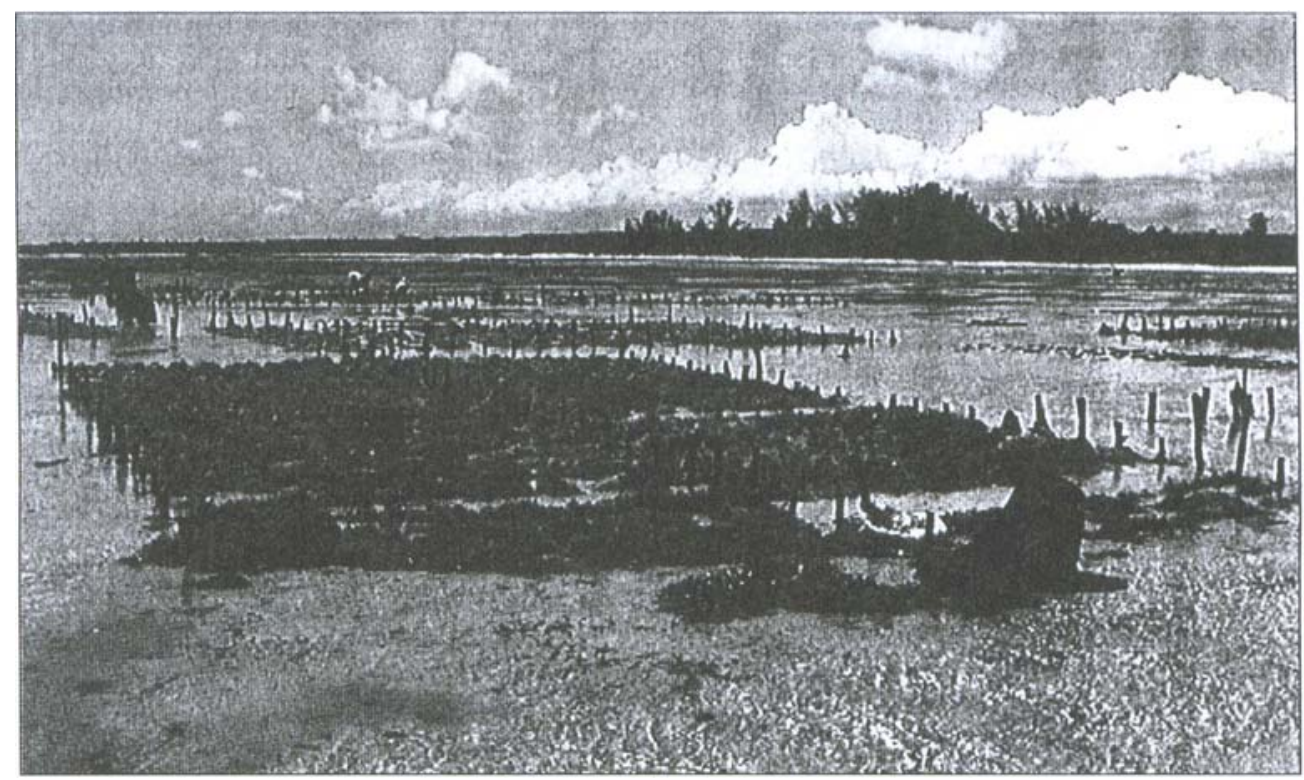

trees and occasional conspicuous baobab trees (Adansonia digitata).

The shoreline is composed of beaches with white siliceous sand and occasional outcrops of consolidated beach-rock or fossilized reefs. The intertidal zone is characterized by sandy-muddy flats, sea grass beds or rocky algal reef platforms that are hinged by coral reefs at their seaward edge. Sheltered shorelines and river outlets are vegetated by mangroves (mainly Rhizophora, Bruguiera, Ceriops, Avicennia, Sonneratia, and Xylocarpus) typical of the east African coast (6). The sea becomes rapidly I deeper offshore and the continental shelf is quite narrow reaching a depth of $200 \mathrm{~m}$ at about $10 \mathrm{~km}$ and then falling steeply to over $3000 \mathrm{~m}$. The coastal waters have a temperature range of 25 to $31^{\circ} \mathrm{C}$ and a salinity of close to 34 to 36 ppt, emanating from the Indian Ocean's westward flowing Equatorial Current that is deflected southwards as it reaches the Mozambican coast.

\section{COASTAL RESOURCES}

Intertidal aI1d shallow-water resources were collected by people walking and wading during low tides across the sandy-muddy tidal flats, seagrass beds, consolidated coral-algal reef platforms, shallow lagoons with tidal pools and channels. Intertidal collectors, mainly women and children, gathered a wide diversity of intertidal organisms including edible bivalves; e.g. Barbatia decusatta (iKope), Modiolus philippinarum (jojobue), Pinctada margaritifera (mbare), Saccostrea cucul/ata (uwala), Tridacna squamosa (nyeta); gastropods including Chicoreus ramosus (ninkhome), Pleuroploca trapezium (ninkoma), Lambis lambis (shidikamondo), Lunella cornata (singine); octopus Octopus cyaneus (ephueja); sea urchins Tripneustes gratilla (unsunkuru); and crabs Portunus pelagicus (nquithi); Calappa hepatica (namavuko). Species caught mainly for sale include ornamental shells; e.g. Cypraea tigris (ucana), Cypraecassis rufa (nafundo), Charonia triton is (nimbululu), Conus textile (epata); holothurians Holothuria scabra (nikojojo); and lobsters Panlilirlis ornatlls (mikalllba). We have listed some of the most common species that we observed including their names in Makua and these compared closely with the extensive lists recorded in the Quirimba archipelago about $100 \mathrm{~km}$ north along the coast (7). We noted that there existed many more specific names in Makua and Kimwani for these organisms than in English or Portuguese.

Intertidal collectors from several villages consistently told us that the resources were decreasing due to increased exploitation after more people migrated to the coast. They said that the number of collectors had increased and that the average size of mussels and other organisms had become significantly smaller and that quantities collected were less. One woman remembered that 15 years ago she could fill a basket from within a small area during 1 hour, but now she had to walk far for several hours just to fill a small bowl, and several other collectors corroborated this observation. Unfortunately no quantitative data is available from scientific studies. People said that they continue to collect these invertebrates because they considered them essential for their diets, especially for pregnant and lactating women as well as for small children; a sauce prepared from boiling these organisms was added to nornlal food. These valuable items were not generally for sale; people collected them for their own family's consumption, especially now that they have become scarce.

Seaweed farming of Elicheuma denticlilatlim and Kappa phycus alvarezii in intertidal lagoons began in Murrebue village in 1998. These red algae were tended and harvested during spring low tides, taken ashore and dried for sale to merchants who then export it for the international carrageenan industry which utiliszes it in food emulsifiers, cosmetics and pharmaceutical products. This activity represented an alternative source of income to users of the intertidal commons. Women farmers informed us that they could earn more by farming seaweeds than by collecting invertebrates, although they considered the seaweed prices to be low, so they encouraged their children to continue collecting invertebrates mainly for family consumption. The few male farmers considered that they could normally earn more from fishing, but that seaweed farming was less risky.

Fishes were also caught in fine-meshed nets and cloths in tidal pools and channels including a wide diversity from several families including Acanthuridae (nanso), Balistidae (hangoko), Holocentridae (kuthalahanga), Labridae (nkorokoro), Lethrinidae (nhambi), Lutjanidae (nsoni), Mugilidae (nkunthage), Scaridae (nipundjo), Serranidae (cheua), Siganidae (safi), etc. These lists were similar to those recorded by other studies in Mecufi (8 10) although there was some variation in the recording of Makua names of fishes.

Deeper water resources (e.g. larger fish, octopus and lobster) were captured in bigger channels and offshore from the reef edge by divers or by fishers from boats. They use basket traps (malema), handlines with hooks, spears, hand-nets, seine-nets 
(ntavi) and gillnets. The most common boats used were dugout outrigger-canoes (casquinhas) or larger planked vessels (machua, ntjo and hithau). There were no signs of overfishing; the sizes of fishes caught were relatively large in comparison to more heavily exploited areas with similar biotopes in Tanzania to the north.

Mangrove forests in Mecufi mainly were mainly found in sheltered creeks and estuaries, but a few trees also grow on more exposed shores. Local people collected firewood, building poles, tannin, fruits, medicines, fishes, crustaceans, and molluscs from the mangrove forests. Our observations and those of local people were that the mangroves were moderately exploited at a sustainable level; there were no signs of deforestation. This contrasted with assertions by donor experts that $70 \%$ of mangroves along the Mozambican coast had been destroyed during the period of civil war due to the influx of people to the coast (11). Instances of beach erosion observed were few and could not be attributed to mangrove deforestation.

The people of Mecufi district were mainly engaged in farming, fishing and harvesting of natural resources both for subsistence and varying degrees of commodity production. Fuelwood, charcoal and whitewash were produced for sale and many people were engaged in artisanal occupations such as basket-making, weaving cloth, ceramics, and carpentry. Most people combined different occupations, often on a seasonal basis (12).

In 1995 , it was recorded (13) that 228 persons were employed in salt production in evaporation pans, 164 persons were employed in services (health, education, administration etc.) and others have jobs connected to various externally funded project activities. There was only one health center for the whole district and one primary school in each village, with the exception of Mecufi headquarters where there was also a secondary school.

There was infrequent traffic between Mecufi and Pemba for transport of goods and enabling people to seek opportunities in the town. Older people commented that many of the youth were abandoning the countryside, and young people explained that they saw little opportunity for themselves in the countryside.

Based upon our interviews with people in the district, we constructed a schematic diagram to represent a simplified depiction of the complexity of a typical Mecufi household's activities, which normally makes use of a wide range of both terrestrial and aquatic resources (Fig. 1). Households did vary considerably in numbers, age, and gender composition. Involvement in or contributions to various fom $1 \mathrm{~s}$ of employment within and outside Mecufi district are not included in this diagram.

\section{BRIEF HISTORY OF CONFLICT AND POST- CONFLICT PERIODS IN MECUFI DISTRICT}

For many centuries the southern part of Cabo Delgado province, including Mecufi district, has been mainly populated by Makuaspeaking people, with neighboring Makonde-speaking people to the north and Lomwe speakers to the south. The province has experienced movements of people, differentiated political processes and influences and contacts with oceanfaring traders (14). A recent study (15) analyzed political state-society relations and processes of democratization in Mecufi district.

The Makua-speaking people have traditions of matrilineal inheritance and matricentric political power (16, 17, and Signe Arnesen, pers. comm.) and this was still evident in their social organization and culture. Despite various external historical patriarchal influences, including Islamic religion, colonialism and associated Catholic doctrines, we did observe unusually strong female status in Mecufi villages where we noticed men carrying babies on their backs and pounding maize. The most influential traditional leader in Mecufi district was the Puiamwene (rainha or queen) named Muaehere Pita Farid, there were severallower puiamwene and also under her influence were 7 male chiefs (regulos - a social category which arose under Portuguese colonialism as a part of their system of incorporating traditional structures into colonial control) (18). The puiamwene reigned until she died and she chose her own successor from among the female members of her family: Puiamwene Muahere Pita Farid informed us that she has chosen one of her granddaughters to succeed her as the next puiamwene.

Coastal trade and cultural interchange brought influences from other parts of the Indian Ocean and the Islamic religion, especially evident in northern coastal Mozambique. Ivory was a major export since the 16th century and slaves were captured and traded during the 18th and 19th centuries. Portuguese invaders

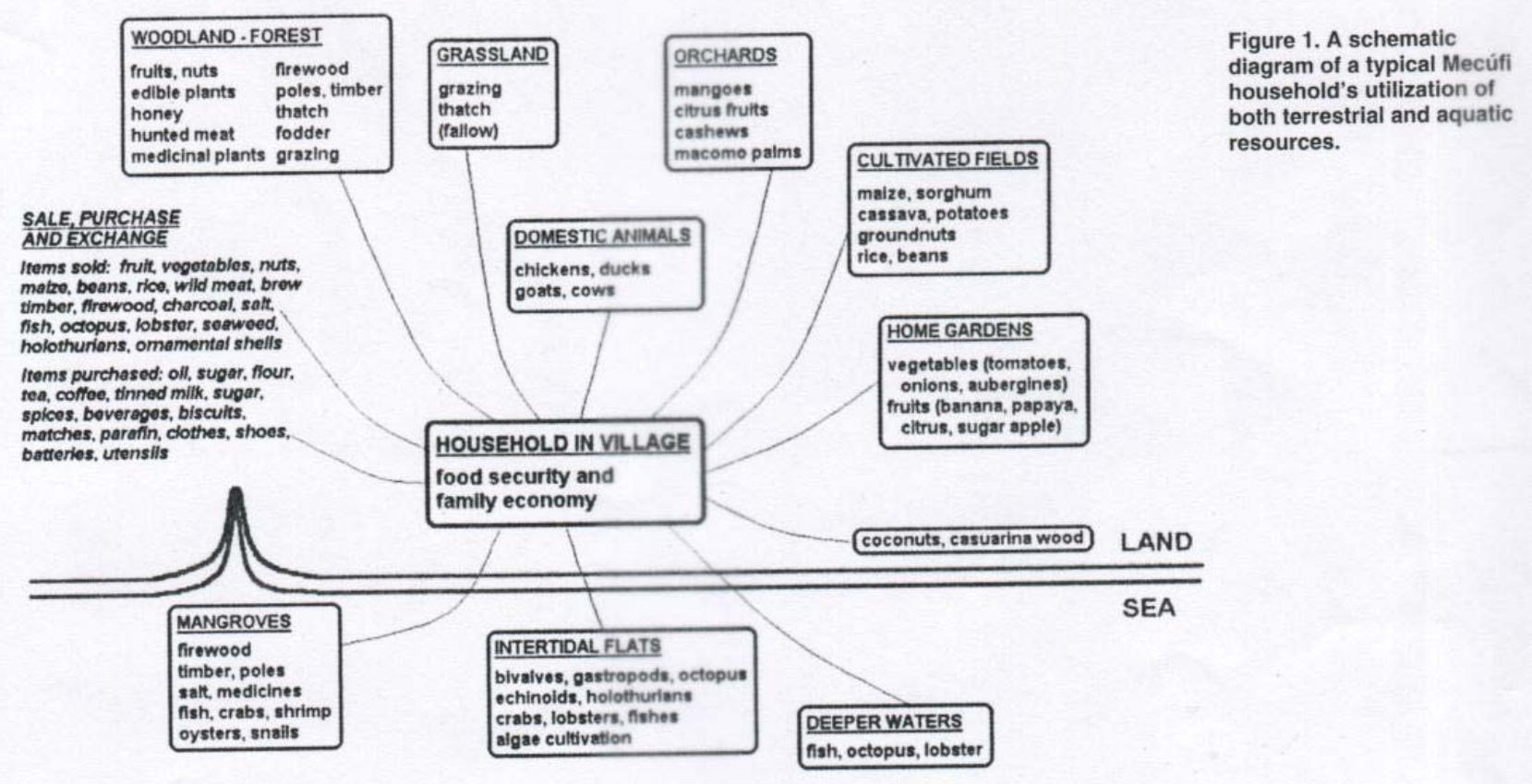


raided the Mozambican coast from the beginning of the 16th century and suppressed local resistance. In 1891, Mozambique was declared a Portuguese colony. The colonial period was characterized by political oppression and racial segregation; in spite of the direct political control exorcized by Portuguese colonialists, 8ritish imperial interests indirectly dominated the economy of Mozambique as a part of the southern African region and as a source of labor $(14,15)$. The struggle for national liberation emerged from anti-colonial resistance coalescing in the formation of Frelimo in 1962, which met with early success in liberating northern parts of Cabo Delgado province. The struggle spread over the country culminating in independence for the country in 1975 .

Following independence, programs of socialist reform and villagization were introduced. There was a mixture of popular support and dissent to these policies. In districts such as Mecufi, collective villages were formed and many traditional leaders were displaced by party officials and elected deputies. Some aspects of traditional culture were decried and varying degrees of disenchantment with these policies became evident in some rural areas. The regimes in Rhodesia and South Africa together with some Portuguese interests supported the formation of Renamo in order to undermine the new Frelimo-led Mozambican government; they conducted a campaign of destabilization and each side accused the other of brutalities (14). Renamo attempted to gain the support of traditional leaders in rural districts such as Mecufi and they formed a fortified camp by the Megaruma and Lurio rivers south of Natuco village and isolated Frelimo influenced villages along the coastal road of the district. The war in Mozambique generated over a million refugees, fleeing into neighboring countries or from the hinterland to the relative safety of the coastal strip. In Mecufi district, the population of the coastal villages doubled and new villages had to be designated. People feared to venture inland away from these villages to tend their fields or harvest forest resources and they generally kept to areas close to the road and shoreline. Theft of crops became a major problem. 80th sides in the conflict had influence in Mecufi district and the conflict was very immediate to peoples' everyday lives. The insecurity and difficulty linked to subsistence farming forced many among the poorer peasants to sell their labor to obtain cash, and rural/urban migrant unemployment in creased dramatically.

In 1992, a Peace Accord was signed and military conflicts ceased. Mecufi district experienced a gradual return to tranquility and safety. Subsequently, reconciliation has been actively pursued through political processes at all levels, the philosophy is to "forgive but not forget" the past conflict. 80th Frelimo and Renamo now function as political parties in the new multi-party system, the former in government and the latter in opposition based upon electoral processes. Support for both parties was evident in discussions with people in Mecufi.

\section{INSTITUTIONS ADDRESSING COASTAL MANAGEMENT ISSUES}

\section{Traditional Institutions}

Prior to colonialism and to the extent that they could exercise influence in the colonial and post-independence periods, traditional leaders in Mecufi paid close attention to the management of natural resources and rights of access to common property (puiamwene Muaehere Pita Farid and regula Mchilo of Sassalane; pers. comm.). A regula normally arbitrated in cases of disagreements or conflicts of interest between individuals or families within a village, whereas the puiamwene presided over differences or conflicts between villages or major land issues such as the localization of a new village to be established. We were informed by puiamwene Muaehere Pita Farid that her grandmother, the former puiamwene of Mecufi, had much influence until 1975, and she allowed local people to fish but outsiders were required to seek permission and then report upon what they had caught before leaving the area.

Puiamwene Muaehere Pita Farid also narrated an example of a particular lagoon that existed south of Natuco where there used to be plenty of fish: in this instance the Puiamwene would decide when the fishing season should start on the basis of her dreams. At the right time she announced that she would travel to a sacred burial place close to the lagoon, and spend the night there: in her sleep she would communicate with a giant spiritual crocodile and persuade it to leave the lagoon to allow safe fishing there. After a further period of time she would have another dream and then announce to the people that the crocodile was returning and that the fishing season was closed again. She then told us that since 1975 the new post-independence authorities had forbidden her to continue this practice since they considered it superstitious; this resulted in continual unregulated fishing in the lagoon, and after some years the fish had become fewer and the lagoon began to accumulate silt and dry up. She said that there was now no lagoon and no fish, and that some people even blame her for this situation; but she said that she did not own the lagoon, she had simply been exercising her spiritual powers until the new authorities had prevented her. The puiamwene told us that the government was now offering her more respect and she has recently switched her allegiance away from the opposition: she would be willing to re-involve herself in resource management if the government requests this. She suggested that regulating the current overexploitation of intertidal resources (due to the influx of people during the conflict and the impact of increased trading) was a case in which she could assist.

The importance of traditional institutions in relation to conflict resolution and natural resource management in 8arue district, Mozambique has been noted (19). The role of local knowledge has been studied in Chwaka village on Unguja island, Tanzania (20) and the importance of traditional management in neighboring coastal Tanzania emphasized (21).

\section{Government Institutions}

Government institutions have a hierarchical structure, from national down to provincial, district, village levels. The Ministry of Environmental Coordination (MICOA) had the main responsibility for coastal zone management, and this involved close inter-sectoral cooperation with several other ministries. At district level, the Administrator of Mecufi informed us of development plans despite limited financial resources, and he was positive towards increased community participation. Our discussion with village authorities revealed their active role in reconciliation processes between former Frelimo and Renamo adversaries and they considered that such enmity was a diminishing problem. We were informed that there was currently little conflict between longstanding residents and immigrant displaced peoples (deslocados) in spite of some initial tensions over land allocations: now there was much intermarriage and general integration. In an occasional argument, the term "deslocados" might still be used in derision, but normally the word was not mentioned any more (this was confirmed in 0111' interviews with other villagers, both longstanding residents and persons who had been forced to migrate to the coastal areas during the conflict). However, the village leaders were worried that growing frustration among unemployed youth from the villages could turn into a new cause of social unrest: they were concerned about coastal management and development that could address such social issues.

The Mecufi Coastal Management Project (Projecto de Gestao Costeira de Mecufi) was commenced in 1993 and it facilitated a number of ecological and social studies carried out in Mecufi district, and a participatory rural appraisal in Natuco village. 


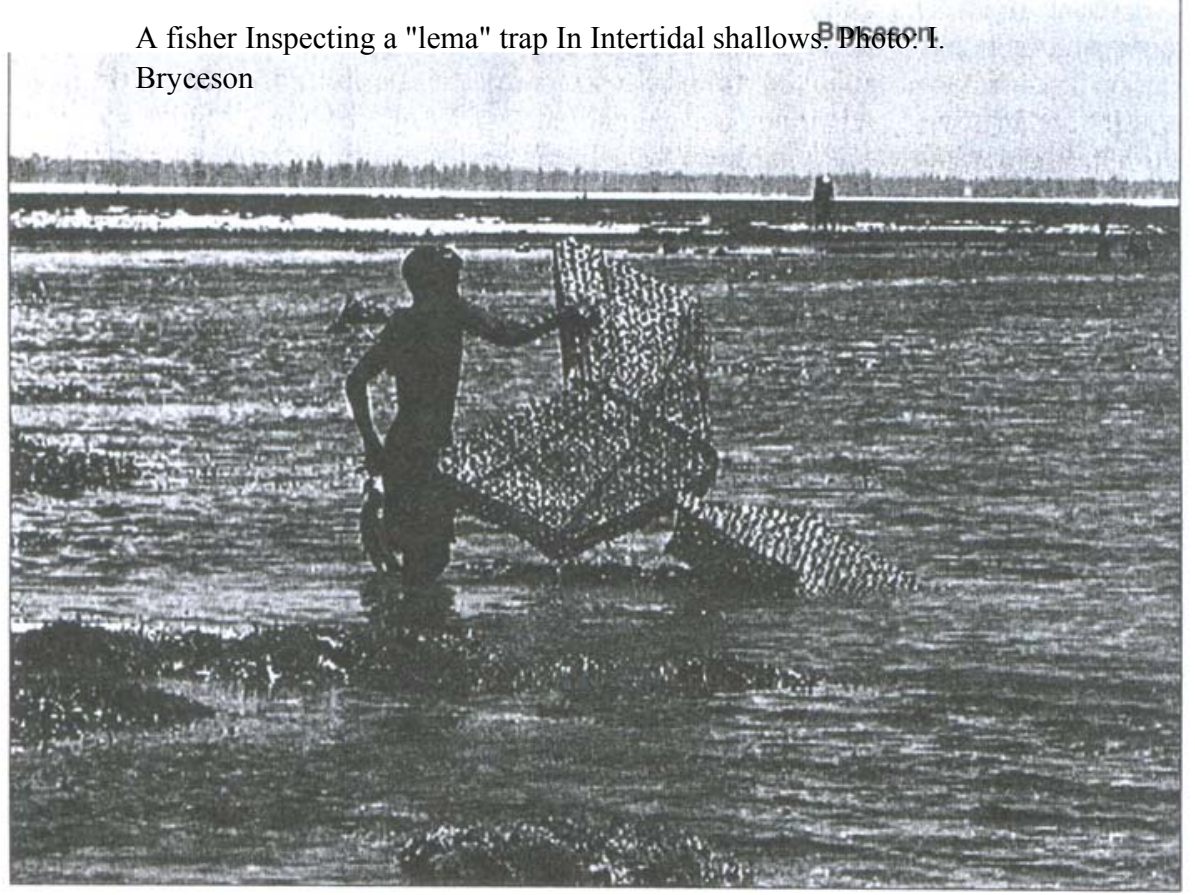

for the farming of Eucheuma denticulatum and Kappaphycus alvarezii at the shore adjacent to Murrebue village. Within I year many women and a few men (about 70 persons) had began to farm these seaweeds and sell them to a Danish company's agents for export. It was interesting to note that the Mecufi Coastal Management Project tried to introduce seaweed farming at Murrebue for several years (22) but the villagers were sceptical, however, when specialists from a commercial company demonstrated the practicalities and guaranteed a market, many villagers almost immediately adopted it. Another commercial entity in Mecufi was a bar adjacent to the beach in an attractive location in Mecufi district centre people visited it from other parts of the district and even from Pemba, especially on weekends: this offered some employment and entertainment to Mecufi residents but also caused cultural friction on occasions. Other forms of tourism were yet to establish a presence in Mecufi, and

They encouraged and provided seeding funds and rotating savings for several village-level development activities such as fishing groups, tree nurseries, goat breeding, ceramics, charcoal and white-wash production. The cultural gap and language differences between intellectuals from Maputo and local villagers emerging from a situation of conflict meant that initial communications were difficult, but the establishment of a permanent presence in Mecufi and long-term contact with people from the area gradually improved their mutual understanding.

Little effective cooperation existed yet between government coastal management initiatives and traditional leaders, but dialog was established and intentions to improve this were expressed.

\section{Research Institutions}

Mozambican developmental research institutions that have studied social and ecological issues in Mecufi include IDPPE and ARP Ac. The Institute for the Development of Small-scale Fisheries (IDPPE Instituto de Desenvolvimento da Pesca de Pequena Escala) conducts sociological and interdisciplinary studies on fishers and fisheries throughout Mozambique. They often coordinate donor-funded projects for development of smallscale fisheries, including rotational savings and credit group approaches, and often based upon principles of comanagement. IDPPE have an office in Pemba and have been involved in research in Mecufi. Archives of Cultural Heritage (ARPAC Arquivo do Patrim6nio Cultural) also does research on cultural aspects related to fishing communities. They have an office in Pemba and have carried out several studies in Mecufi. The University of Eduardo Mondlane has also been involved in many natural and social science studies in Mecufi.

Civil and Commercial Organizations

Civil organizations (also often referred t9 as nongovernmental organizations) relating to coastal resource use and management in Mecufi district include a number of village-level associations and cooperatives, village management committees and community organizations in addition to international organizations such as Humanistic Institute for Development Cooperation (HIVOS) and Swiss Association for International Cooperation (HEL VET AS).

Commercial interests in seaweed farming, based upon their success in Zanzibar and other parts of Tanzania's coast, came to Mecufi district careful regulation of any such proposed interventions or ventures should be considered very cautiously (23) in relation to the interests of the people of Mecufi.

\section{Donors and Global Financial Institutions}

International donor organizations such as Sida (Sweden), DANIDA (Denmark) and NORAD (Norway) have been mentioned above. Their funding was important in the context of a country such as Mozambique with meager financial resources of their own. They sometimes provided support to coastal management efforts and projects, but occasionally external factors, changes of personnel or new priorities made their support somewhat unpredictable.

The World Bank, International Monetary Fund and other global financial institutions provided funds for environmental projects, but they also affected the national macro-economy of Mozambique by imposing structural adjustment programs and requiring liberalization as conditionality for receiving loans. These macro-nolicies have been shown to disadvantage the

\section{FUTURE PROSPECTS FOR COASTAL MANAGEMENT IN MECUFI}

It was evident from our observations and discussions with people in Mecufi that peace, political stability, and democratic processes are necessary prerequisites for positive coastal development. Conflict and forced migration of people caused suffering and disrupted their lives to an extent that coastal management could not function properly.

In the current situation, the principal threat to the interests of the people of coastal districts such as Mecufi is loss of their common property and land rights. A basic condition for coastal development is security for coastal peoples' land tenure, and rights of access to common resources (26). The rights of poor people in rural areas in Mozambique have been strengthened by the introduction of the new Land Law of 1997, Regulation for Environmental Impacts Assessment of 1998 and Forestry and Wildlife Law of 1999, which are intended to protect the rights of peasant farmers and rural communities. These laws and regulations are based upon recognition of user rights such that any intervening private individuals or commercial interests are required to hold consultations with local communities and obtain written 
consent of the district administrator prior to gaining permission to use land (27-29). However, the practicing of these laws and upholding of regulations will depend upon state authorities at various levels: it is therefore essential to provide information to local people about their rights and to ensure transparent and accountable procedures.

Mecufi district will surely be increasingly subjected to pressures to accommodate private investments, some with foreign capital involved. These may be cement factories, coastal tourism facilities or shrimp farms, etc. Some investments may provide opportunities for employment or indirect benefits to some people, but other types of development could harm the interests of poor people, further pauperising or marginalizing them from their traditional rights to common resources thereby exacerbating problems of poverty. Environmental impact assessment processes still do not integrate social considerations adequately and there are few public hearings of these. Government authorities should monitor the practices of monopolistic multinational corporations investing in coastal areas such as Mecufi.

The conservation of coastal ecosystems and their biodiversity will depend upon support and participation of local communities and various institutions active in Mecufi. But conservationists should take care not to regard local communities as inexpensive labor to be deceived with promises of conditional "participation". Appropriate legislation should be further developed in order to assure the sustainable utilization of renewable natural resources and maintenance of key ecosystem services compatible with the development aspirations of coastal peoples. Mozambique has banned commercial collection and export of cor-

\section{References and Notes}

1. Massinga, A. 1996. Mecufi coastal zone management project. In: tegrated Coastal Zone Management in Mozambique. Lundin, C.G. and Linden, (eds) World Bank and Sida, pp. 7-89.

2. Comissao Nacional do Meio Ambiente, CNA 1992. Project Document for Mecufi

Coastal Zone Management Project. Maputo, Mozambique. $32 \mathrm{pp}$.
3. INE 1999. Projeccoes anuais da populacao por distritos, 1997-2010 M09ambique

Volume 3 (regiao norte). (In Portuguese)

4. Inguane, A. 1994. 0 Ambiente Natural de Costa do Distrito de Mecufi. Report to CNA. 40 pp. (In Portuguese)

5. Hatton, 1 and Massinga, A. 1994. The Natural Resources of Mecufi District.

Mecufi Coastal Zone Management Project, Ministry of Environmental

Coordination, Maputo. $44 \mathrm{pp}$.

6. Semesi, A.K. and Howell, K. 1992. The Mangroves of the East African

Region. UNEP Publication, Nairobi. $45 \mathrm{pp}$

7. Whittington, M.W., Antonio, C.M., Heasman, M.S., Myers, M. and StanwellSmith, D. 1998. Marine Biological and Resource Use Surveys of the Quirimba Smith, D. 1998. Marine Biological and Resource Use Surveys of the Quirimba
Archipelago, Mozambique. Report to Society for Environmental Exploration, London and MICOA, Mozambique. $62 \mathrm{pp}$.

8. Pacule, H., Pinto, M.A. and Dengo, A. 1996. Preliminary Analysis of the Fisheries of the District of Mecufi. Report to CNA. 29 pp

9. Bouju, S. and Garette, A. 1996. Catalogo dos Peixes Capturados na Provincia de Cabo Delgado. Report to IDPPE, Maputo. 104 pp. (In Portuguese).

10. Loureiro, N.L. 1998. Estudo da Ictiofauna Coralina e Pequeira do Distrito de MeCliji, Provincia de Cabo Delgado. Tese de Licenciatura, Universidade Eduardo Mandlane, Mozambique. 70 pp. (In Portuguese).

II. World Resources Institute 1991. Mozambique: Integrating Environmenta l Issues into a Strategy for Sustainable Development. Report by World Resources Institute for World Bank http://www.wri.orglwdces/m091 484.html

12. Massinga, A and dos Santos, C. 1998. Mecufi Coastal Zone Management Project. Pa per presented at Workshop on experiences in local and community integrated coastal zone management projects. 4"- 6' March 1998 Zanzibar, Tanzania. $15 \mathrm{pp}$.

13. Tovele, V. 1996. Ambiente Fisico e Socio-economico do Distrito de Mecufi. Report to CAN, Maputo. 23 pp. (In Portuguese).

14. Newitt, M. 1994. A History of Mozambique. Bloomington, Indiana University Press.679 pp.

15. Harrison, G. 2000. The Politics of Democratisation in Rural Mozambique: Grassroots Governance in Mecufi. Edwin Mellin Press, Lewiston, N.Y. 223 pp.

16. Rita-Ferreira, A. 1982. Fixafiio Portuguesa e Histaria Pre-colonial de Mofambique. Lisbon. Junta de Investiga90es Cientificas do Ultramar. 127 pp. (In Portuguese)

17. Mbwiliza, IF. 1991. A History of Commodity Production in Makuani 16001900: Mer cantilist Accumulation and Imperialist Domination. Dar es Salaam University Press, Dar es Salaam. $152 \mathrm{pp}$.

18. Mucavele, 1A. 1995.0 Poder Tradicional em Mofambique: 0 Caso de

Afecufi. Re
port to CNA. 42 pp. (In Portuguese).

19. Artur, D.R. and Virtanen, P. 1999. The role of traditional authority in contlict resolution in Mozambique: a case study from Serra-ChOa, Barue district. Paper presented at KATU Workshop, Maputo, June 1999. http://www.katu-network.fi/ArtikkelitlkiIja2/ content2.htm

20. Tobisson, E., Andersson, J., Ngazi, Z., Rydberg, L. and CederlOf, U. 1998. Tides, monsoons and seabed: local knowledge and practice in Chwaka Bay, als and ornamental fishes while the capacity to regulate such extractive practices is lacking. Public participation is still weak in Mozambique and human capacity in state organs vested with responsibility for coastal conservation and management is considered still low though improving (30).

The management of common property coastal resources is highly complex. We noted in this study of Mecufi district that traditional customary authorities appeared to have dealt with conflicts over natural resources among local communities efficiently and they seemed to have a degree of legitimacy among ordinary people; they functioned to some extent even during the period of civil war when other institutions were incapacitated. Similar traditional systems of coastal management have also been recognized as being valuable in other parts of east Africa (21). Mozambicans have recognized the importance of cooperation between traditional and state institutions and introduced bold legislation $(31,32)$, and it is crucial that these be practiced accordingly. In the post-conflict and peace-time situation it would seem advantageous for state authorities at various levels to continue to find appropriate ways to further work together with traditional authorities who have genuine legitimacy among the local population and involve them more deeply in addressing coastal management issues and other natural resource questions. It is essential that such involvement be based upon democratic procedures. Other countries could also learn from the experience that Mozambique already has in this respect. Any genuine improvement in coastal management in Mecufi district will entail development of the coastal peoples by themselves as they strive their rights and improvement of their living situation.

24. Gibbon, P. 1996. Everything's for sale: some preliminary reflections on economic liberalisation, forms of production and environmental degradation in Tanzania's waters and forests. CDR Working Paper, 96.2.

25. Reed, D. 2000. Economic Change, Governance and Natural Resource Wealth: the Political Economy of Change in Southern Africa. Earthscan Publications, London. $168 \mathrm{pp}$.

26. Shivji, I.G., 1998 Not Yet Democracy: Reforming Land Tenure in Tanzania.

IIED, Hakiardhi, Dar es Salaam. 132 pp.

27. Negrao, J. 1999. The Land Campaign in Mozambique. An OXFAM

publication. http://www . oxfam. org. uk/landri ghts/M ozcam p. rtf

28. United Nations 2000. Ensuring Small Farmers' Access to Land. African

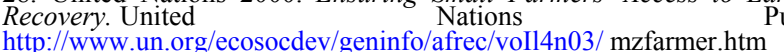

29. Norfolk, S Nhantumbo, Pereira, and Matsimbe Z 2001. Towards democratic management ofresources natural: the case of Derre and Bajone. Working paper presented at Worshop on Accountability, Decentralisation and the Environment: local democracy and natural resources in Sub-Saharan Africa, 15"'-19" October $200 \mathrm{I}$.

30. Motta, H. 2000. Integrated Coastal Zone Management in Mozambique: From Seychelles to Maputo, 1996-2000. http://www.seacam.mz Proceedings $\% 20 \%$ WebAnnexes $\% 5$ CPo w er\%2 Opo ints \%5 M ozambi q ue $\%$ Mr. $\% 20 \% 20$ Pacul e. pp t

31. Hanlon, J. 2000. New Decree Recognises 'Traditional Chiefs'. Mozambique Peace Process Bulletin, 25. http://www.mol.co.mz!noticias/bulletin/ppb25c.html

32. Black, R., Harrison, E., Admassie, Y., Pankhurst, A., Yibabie Watson, E., Shafer, J., Matakala, P., Serra, A.T. and Ribeiro, A. 2002 Conflict, 'Postcoriflict', and Traditional Authorities. MARENA Briefing. http://www.geog.susx.ac.uk/research/development/ marena/pdf/mozambique/MozO l.pdf

lan Bryceson is a coastal and marine ecologist from Tanzania with 30 years of experience in tropical marine ecology and international aquaculture. He is currently working as research professor at the Centre for International Environment and Development Studies, Noragric, Agricultural University of Norway, 1432 As, Norway and as adjunct professor at the Department of Fisheries and Marine Biology, University of Bergen. He was funded by the Norwegian Research Council for this study. His address: Noragric, Agricultural University of Norway, Box 5001, N-1432 As, Norway.

E-mail: ian.bryceson@noragric.nlh.no

Alfredo Massinga is Vice-Minister of Fisheries in the Government of Mozambique. He has an MSc in fisheries management and biology and he worked as coordinator of the Mecufi Coastal Zone Management Project under the Ministry of Environmental

Coordination (Ministerio para a Coordena_ao da Ac_ao

Ambiental, MICOA) from 1992 t01997. His address:

Ministry of Fisheries, P.O. Box 1723, Maputo,

Mozambique.

E-mail: alfredo@mozpesca.org 